\begin{abstract}
This paper analyzes the welfare benefits from falling relative prices of IT (information technology) goods across a wide range of countries. We find, using two separate methodologies and datasets, that welfare benefits mainly accrue to users of IT, not their producers, because of falling relative prices. This is important, as IT production and use are highly differentiated across countries, and implies that earlier work on how IT production affects real GDP, while useful in calibrating the overall benefits of the IT revolution, are a less valuable way of assessing the distribution of benefits.
\end{abstract}

JEL classification: D60, F43, O47, O57

This paper was produced as part of the Centre's Technology and Growth Programme

\title{
Acknowledgements
}

Tamim Bayoumi is affiliated to the International Monetary Fund, Washington, DC. Email: tbayoumi@imf.org

Markus Haacker is a member of the IMF African Department, Washington DC and an associate of the Centre for Economic Performance, London School of Economics. Email: MHAACKER@imf.org.

Published by

Centre for Economic Performance

London School of Economics and Political Science

Houghton Street

London WC2A 2AE

(C) T. Bayoumi and M. Haacker, submitted August 2002

ISBN 0753015854

Individual copy price: $£ 5$ 


\section{It's Not What You Make, It's How You Use IT: \\ Measuring the Welfare Benefits of the IT Revolution \\ Across Countries}

\section{Tamim Bayoumi and Markus Haacker}

\section{September 2002}

1. Introduction 1

2. Current Estimates of the Impact of IT on the Economy 3

2.1 Accounting for rapid changes of relative prices of IT goods 3

2.2 Estimating the contribution of the IT sector to economic growth 5

3. The Impact of the IT Sector on Real GDP and Domestic Demand 6

3.1 Data issues 6

3.2 Estimating the impact of IT price falls on real GDP and domestic demand 8

4. Welfare Benefits of Falling Relative Prices of IT Goods 10

$\begin{array}{lll}4.1 & \text { Empirical estimates } & 13\end{array}$

5. Summary and Conclusions 18

Tables $\quad 19$

Figures $\quad 25$

$\begin{array}{ll}\text { Appendix } & 27\end{array}$

References $\quad 30$

The Centre for Economic Performance is financed by the Economic and Social Research Council 


\section{Introduction}

The "new economy" (by which we mean the information technology (IT) sector) has gone through some notable ups and downs over a short period, from unbridled optimism through much of 2000 to skepticism after the crash in IT equity prices later that year. ${ }^{1}$ Academic work on this subject has gone through a similar cycle, with a series of relatively optimistic estimates of its impact on productivity being produced, followed by a pause in such work.

This paper (which was started during the optimistic phase of IT analysis) looks beyond the extensive literature that focuses on the impact of IT on output and productivity ${ }^{2}$ to examine a different issue - where are the welfare benefits of the expansion of the IT sector located? Or, as Cicero put it many years ago, cui bono (who profits)? This is important, as IT production and sales are highly differentiated across countries, with production (as a share of output) concentrated in a small number of countries, most notably in emerging market countries of Asia, and sales largest in many of the richer countries, such as the United States. We come to the stark and important conclusion that owing to rapidly falling relative prices, the welfare benefits accrue mainly to consumers of IT goods, not their producers. In short, the impact on real GDP is a highly misleading measure of the distribution of the benefits of IT.

We should emphasize that this paper looks at the direct impact of falling IT prices on welfare, not at the benefit gains made in the rest of the economy owing to a reorganization of production. The welfare benefits of any generalpurpose technology (such as IT, electricity, the railways, or steam power) come through two channels. ${ }^{3}$ Initially, the main benefits are associated with the fall in relative prices of existing products and the creation of new products - this is the issue we investigate. Over the longer run, total factor productivity rises economy-wide owing to a reorganization of production based on use of these goods by other producers. Views differ on the evidence for a generalized increase in productivity associated with the use of IT equipment in the United States, the country in which IT use is the most advanced so far, and its impact is likely to be even smaller for other countries,

\footnotetext{
${ }^{1}$ A pattern also typical of earlier "all-purpose" technology revolutions, see IMF (2001).

${ }^{2}$ Key early references are Oliner and Sichel (2000) and Gordon (2000).

${ }^{3}$ See Crafts (2000).
} 
justifying the focus in this paper. ${ }^{4}$ More generally, these spillovers are, in any case, associated with the use of IT goods by other industries, underlining our central point that the main benefits of the IT revolution are accruing to countries that buy IT goods, rather than those that produce them.

We illustrate our basic point through two analytic exercises that use separate methodologies and datasets:

The first exercise takes a comprehensive look at the impact of falling IT prices on real GDP and real domestic demand across a wide range of countries using a consistent dataset. The benefits to real GDP are highly skewed to a small number of countries with large IT sectors relative to output. However, because these countries export most of their production, they face a constant deterioration of their terms of trade as the relative prices of IT goods fall. As a result, the benefits to domestic demand are largest for major consuming countries, most notably the United States.

The second exercise measures welfare directly by calculating "social savings," a variant of consumer surplus used in earlier work on technological revolutions - again across a wide range of countries using a consistent dataset. The results again indicate that the benefits accrue to the main users of IT goods, not producers.

The remainder of the paper is organized as follows. The next section provides some background by summarizing how statistical agencies have responded to the rapid changes in relative prices caused by the IT revolution as well as existing work on the impact of IT on output and productivity. Section 3 provides some illustrative estimates of the impact of falling IT prices on real GDP and real domestic demand, emphasizing the very different responses in individual cases. The following section estimates IT-related welfare gains by calculating social saving across a wide range of countries, while Section 5 summarizes and concludes.

\footnotetext{
${ }^{4}$ The United States is the country most analyzed in this regard, largely because IT use is the most advanced there. See Bailey (2001) and Stiroh (2001) for a discussion of recent studies using different empirical approaches.
} 


\section{Current Estimates of the Impact of IT on the Economy}

Existing work on the contribution of IT to the economy falls into two broad categories: the improvement of the underlying national income statistics to take account of rapid changes in relative prices, and estimates of the contributions to real output growth from capital (with the IT capital stock differentiated from the non-IT capital stock), labor, and total factor productivity (again differentiating between the IT sector and the rest of the economy). Most of the initial work in both areas focused on the United States.

\subsection{Accounting for rapid changes of relative prices of IT goods}

In response to rapid changes in relative prices associated with the IT revolution, the US national income and product accounts (NIPA) - increasingly followed by other official agencies - have introduced two major modifications, both of which are important for some of the calculations we perform below. ${ }^{5}$ The first involves estimating the fall in prices caused by technologically inspired improvements in IT goods. The difficulty is that most IT goods (such as computers) incorporate a wide range of different capabilities (RAM, memory, drives, etc.), which may have increased at different rates, and that some of these capabilities have been newly introduced as technology has improved. To take account of this, changes in the prices of computers and related IT goods are measured through "hedonic" price indices, in which econometric estimates of prices across a range of goods with differing capabilities are used to get an estimate of the value of each component. Estimated values of individual characteristics are then combined to get an estimated price of a typical computer. As shown in Table 1 for the United States, these hedonic price indices show quite dramatic falls in the relative prices of many IT goods, here defined as the prices of IT goods relative to the GDP deflator.

The second adjustment regards the weighting of the increases in real output/demand across different sectors/types of goods. Traditionally, the aggregate increase in real activity in the national accounts is calculated by means of a Laspeyres index, which means that relative prices for a specific base year are used as weights. For example,

\footnotetext{
${ }^{5}$ For a more in depth discussion of these issues, see Whelan (2000).
} 


$$
g_{Q, t}=\frac{\sum_{i=1}^{n} P_{i, 0} \cdot Q_{i, t}}{\sum_{i=1}^{n} P_{i, 0} \cdot Q_{i, t-1}}-1,
$$

where $g_{Q, t}$ is the growth rate of aggregate $Q$ at time $t, P_{i, 0}$ is the price of good $i$ in the base period, and $Q_{i, t}$ is the quantity of good $i$ in period $t$. This procedure works well when there are relatively small changes in relative prices, as the distortions caused by switching from one base year to another are quite limited and it makes comparisons across years relatively simple. However, such a procedure is much less well suited for a situation in which relative prices are changing rapidly. ${ }^{6}$

To avoid excessive reliance on prices in a single base year, the United States national income and product accounts (and those of several other countries, including France) have switched to chain weighting. The weights applied are updated every year, and the increase in real activity in for any sector is measured using the geometric average of a Laspeyres index (in which historic prices are used as weights, see Eq. (1)) and a Paasche index (in which current prices are used to weight the components of demand), a calculation called a Fischer "ideal" index. ${ }^{7}$

Thus, the increase in real activity between any year and the previous one is measured by:

$$
g_{Q, t}=\sqrt{\frac{\sum_{i=1}^{n} P_{i, t} \cdot Q_{i, t}}{\sum_{i=1}^{n} P_{i, t} \cdot Q_{i, t-1}} \frac{\sum_{i=1}^{n} P_{i, t-1} \cdot Q_{i, t}}{\sum_{i=1}^{n} P_{i, t-1} \cdot Q_{i, t-1}}}-1,
$$

Chain weighting is an obvious approach to take over a period of rapid relative price changes as it makes the growth in real activity in the national income accounts independent of the base year chosen for measuring the size of the aggregate economy. However, it also makes comparisons of behavior across sectors across several years more complicated. In

\footnotetext{
${ }^{6}$ For example, if the relative price of a typical computer falls by around two-thirds between 1995 and 2000 (as it has been estimated to have done in the United States), then if 1995 prices continue to be used to value computers there will be a large increase in output of the consumer industry and investment in IT goods. When the accounts are switched to 2000 prices, however, this effect will be reduced by two-thirds, because the Laspeyres approach fails to take account of the fact that as a good becomes cheaper it is used less efficiently.

${ }^{7}$ Whelan (2000).
} 
particular, real dollar increases in the components of output/expenditure over several years no longer sum to the increase of the relevant aggregate value.

\subsection{Estimating the contribution of the IT sector to economic growth}

The existing literature on the macroeconomic impact of the IT revolution focuses almost exclusively on the impact on real GDP and/or productivity. The typical approach is to look at the relative contribution of IT and non-IT capital, labor, and total factor productivity (TFP) to real output growth starts from a Cobb-Douglas production function with constant returns to scale, with IT and non-IT capital differentiated: ${ }^{8}$

$$
y-l=a_{k}\left(b_{I T} k_{I T}+b_{n o n-I T} k_{n o n-I T}\right)+t f p,
$$

where $y, l, k_{I T}, k_{n o n-I T}$, and $t f p$ are the logarithms of real output, labor, the real IT capital stock, the real non-IT capital stock, and total factor productivity, respectively, $a_{k}$ stands for the share of profits the total economy, $b_{I T}$ is the nominal share of IT capital in the overall capital stock, and $b_{n o n-I T}$ is the share of non-IT capital in the overall capital stock.

Using this approach, various authors have estimated the contribution to overall growth made by IT investment, as well as evidence for increments to TFP growth created by IT. This is useful as it summarizes the size of the potential benefits from the IT revolution, but distracts from the issue addressed in this paper, namely who ultimately benefits. The results from the US literature indicate that IT-related capital deepening provides a significant component of the recent increase in activity (Table 2). As the nominal share of IT investment in GDP stayed largely constant, this primarily reflects changes in the quality of IT investment, as measured by using hedonic price indices. There has also been an increase in total factor productivity, although assigning this between the IT sector itself, IT spillovers, and other factors such as the cycle or more efficient markets has been difficult. ${ }^{9}$ Using the decline in prices of IT-related goods as a measure for productivity gains in the IT sector, the

\footnotetext{
${ }^{8}$ See Bailey (2001) for a wide-ranging survey on the United States, as well as Oliner and Sichel (2000), Gordon (2000, 2001), Jorgenson and Stiroh (2000), and Stiroh (2001). For other countries, see Cardarelli (2001) on Australia; Economic Planning Agency (2000) on Japan; Estevao and Levy (2000) and Mairesse, Cette, and Kocoglu (2000) on France, Oulton (2001) and Kodres (2001) for the United Kingdom, and Lee and Khatri (2001) for east Asia.

${ }^{9}$ Stiroh (2001), analyzing the acceleration in labor productivity across US industries, finds that the acceleration of productivity is connected with IT intensity, but is unable to identify whether this reflects higher TFP growth or capital deepening.
} 
studies referred to in Table 2 estimate that $1 / 4$ percent or so of the acceleration in US total factor productivity comes from within the IT sector.

\section{The Impact of the IT Sector on Real GDP and Domestic Demand}

Given that the location of production of IT goods and their final purchase are quite distinct across countries, it is important to ask whether the benefits of productivity gains in the IT sector go to those who produce and are major exporters of IT goods (such as Singapore, Malaysia, and Ireland) or those who are major importers and users of IT goods (such as Australia). We provide an answer to this issue in this section by first calculating the potential impact of technological progress in the production of IT goods on real output growth across a wide range of countries, using a common methodology and data set on IT output. ${ }^{10}$ These results are then contrasted with a calculation of the benefits to real domestic demand based on the same basic methodology but using common data on purchases of IT goods. The impact of falling IT prices on real domestic demand is a better measure of welfare than real output, as consumption is the ultimate objective of economic activity. As the major producers of IT goods export most of their IT output, we find that the welfare gains associated with productivity gains in the IT sector dissipate. Indeed, gains to real GDP are insignificantly related to gains to domestic demand, although a weak positive relationship is found when relative incomes are taken into account.

\subsection{Data issues}

Sufficiently detailed data on IT production or expenditure from national accounts are not available for a large number of countries, and the classification of products and methods used for estimating the prices of IT goods may differ across countries. The analysis in this section is therefore based on private sector estimates of sales of and expenditure on various

\footnotetext{
${ }^{10}$ Cross-country studies of the impact of IT on output include Colecchia (2001), Daveri (2001), Roeger (2001), Schreyer (2000), Lee and Pilat (2001) and Van Ark (2001). Our results covers a wider range of countries and focus on real output and real domestic demand, using a simpler methodology that focuses on actual production rather than inputs of factors of production.
} 
components of IT goods from Reed's Yearbook of World Electronics Data. ${ }^{11}$ As is common in the literature, the price indices for the respective IT goods are based on hedonic prices from the US national income and product accounts and from the US producer price indices, adjusted for changes in the exchange rate. The impact of the IT sector on GDP and domestic demand is then estimated using a chain-aggregated quantity index.

The Reed Electronics Research database provides annual data on the production and on purchases of IT-related goods from 32 countries, starting in $1985 .{ }^{12}$ We focus on three broad aggregates, for which hedonic prices indices from the US official statistics could be lined up with the Reed data: electronic data processing (EDP) equipment; communications equipment (Reed's telecommunications category - covering switching equipment, transmission equipment, telephone sets, facsimile machines, and some other goods — as well as parts of the "communications and radar" category - e.g. mobile phones, other radio communication, cable and CCTV, and other public broadcasting); and semi-conductors (Reed category active components). However, in some cases the Reed data on EDP expenditure were found to be problematic, with implausibly high domestic sales for some of the main exporters of these goods (e.g. 8 percent of GDP for Singapore, followed by 2.4 percent for Ireland, and 2.2 percent for Malaysia). This may reflect double counting of intermediate EDP goods, or misclassification of exports as domestic sales. The data on EDP expenditure have therefore been adjusted, using total expenditure on EDP goods from the Reed database (so that the numbers are consistent with the data on EDP production), but expenditure weights for IT hardware from the WITSA database, which seems less affected by misclassification of sales. ${ }^{13}$

To obtain the aggregate value of IT production and expenditure, it is necessary to take into account that most active components are used as intermediates in computers or communications equipment. In the absence of more detailed data on the use of active components, total expenditure on IT goods is defined as the sum of expenditure on EDP goods and communication equipment. Total production of IT goods is defined as the sum of

\footnotetext{
${ }^{11}$ See Reed Electronics Research, (2001).

12 See Table 3 for a list of countries covered.

13 The WITS A database is described in more detail in Section 4, below, where it is used for estimating social savings associated with the use of IT goods. While the Digital Planet database comprises a larger number of countries and, unlike World Electronics Data, covers software, it provides data on sales only (and not on production), covers a shorter period, and is less disaggregated.
} 
the production of EDP goods and communication equipment, plus net exports (production minus expenditure) of active components. Thus, while our data may still over- or understate the total value of IT production in a country if there is significant net trade in intermediates (excluding active components), we do account for those intermediates for which technological progress has been most pronounced.

National IT price indices are calculated by adjusting the US hedonic price indices for changes in the exchange rate. This is a good approximation to the extent that IT goods are tradable and markups stay constant over time; it is used by several official statistical agencies (e.g. Denmark and Australia) as well as other researchers. ${ }^{14}$ While the implied view that there is full pass-through of exchange rate changes could be questioned, Table A3 in the appendix suggests that most of the variation of IT prices is associated with productivity gains rather than changes in the exchange rate. In addition, it does seem to hold fairly well in at least one case where separate hedonic prices indices have been calculated by national authorities (France, see Deutsche Bank, 2001).

\subsection{Estimating the impact of IT price falls on real GDP and domestic demand}

The impact of falling IT prices on real GDP and domestic demand is calculated by comparing the path of activity assuming that IT goods were priced at the GDP/domestic demand deflator with the path of output using hedonic price indices, chain weighting, and data on IT output and sales. Hence, the thought experiment is: what happens if an average good with no relative price movement is replaced by IT goods with their rapidly falling relative prices? For example, for real absorption, the growth rate using chain weighting from one year to another is calculated as:

$$
g_{A B S, t}=\sqrt{\frac{\sum_{i=1}^{n} E_{i, t}}{\sum_{i=1}^{n} \frac{P_{i, t}}{P_{i, t-1}} \cdot E_{i, t-1}} \frac{\sum_{i=1}^{n} \frac{P_{i, t-1}}{P_{i, t}} \cdot E_{i, t}}{\sum_{i=1}^{n} E_{i, t-1}}}-1,
$$

14 An alternative that is sometimes used is a "harmonized index," whereby the change in relative prices of IT goods for a respective country is set equal to the change in relative prices for the United States. See, for example, Schreyer (2000). 
where $P_{i, t}$ stands for the price of good $i$ (either IT or non-IT), and $E_{i, t}$ stands for expenditure on the respective good. ${ }^{15}$ For countries that use hedonic price indices the GDP and absorption deflators were adjusted to take this into account.

Tables 3 and 4 show the estimates of the impact of the IT sector on the growth rates of real GDP and real domestic demand over the years 1996-2000. ${ }^{16}$ As a measure for technological progress in the IT sector, Table 3 also reports the average annual change in the prices of IT goods (calculated on an annual basis, using a chain-weighted index) relative to the GDP deflator, over the years 1996-2000. These differ significantly across countries differences in the composition of IT production and changes in exchange rates. ${ }^{18}$ In particular, the change in relative prices of communications equipment is much smaller than for EDP equipment and active components. Thus, for a country like Finland, which produces mainly communications equipment, and is a significant net importer of active components, the change in relative prices of IT goods is relatively small. Fluctuations in exchange rates have some impact, especially for producers of telecommunications equipment, where world market prices have not declined as quickly as for EDP equipment and active components, and help to explain why for countries like Denmark, Finland, and Sweden, the change in relative prices of IT goods is positive.

The IT sector has expanded rapidly throughout the sample, as evidenced by IT sector growth rates for 1996-2000 in the region of 30 to 55 percent for nine countries. The final column in Table 3 estimates of the contribution of productivity gains in the IT sector. For the main producers, the gains from IT-related productivity growth have been substantial, amounting to 6.7 percent annually for Singapore, 3.3 percent for Malaysia, and 2.1 percent for Ireland, and around 0.3 percent for the United States (consistent with earlier work), the United Kingdom, and Japan.

However, as the prices of IT-related goods have fallen substantially, to the extent that these goods have been exported, there is a terms of trade loss that substantially erodes these gains, as is vividly illustrated in Table 4 and Figure 1 . The contribution of IT to domestic demand is much more equally distributed across countries than IT production. As a

\footnotetext{
15 This formula is equivalent to that in Eq. (2), which is specified in terms of prices and quantities, rather than nominal expenditure. See Whe lan (2000) for an extensive discussion of chain-weighted indices.

16 Tables A1 and A2 provide further details on the level and composition of IT production and demand across countries.

${ }^{18}$ See appendix for data on the composition of IT production and absorption.
} 
percentage of GDP, IT-related demand ranged from 2.4 percent (the United States) to 0.4 percent of GDP (India) in 2000. Excluding countries worst affected by the Asian crisis, ITrelated domestic demand has grown by 20 percent (Italy) to 36 percent (Taiwan) over the 1996-2000 period. As not only the level, but also the composition of IT-related spending differ less across countries than for production, the differences in price indices are less pronounced, and largely reflect changes in exchange rates. Corresponding to the pattern of IT-related expenditure, the positive impact of productivity gains in the IT-sector on real domestic demand growth is much less concentrated than for IT production, and positively correlated with per-capita income. The highest gains accrue to the United States, while Australia, which is not a significant producer of IT-related goods, is among the six countries realizing the highest gains. Indeed, regressions indicate that gains to real GDP are not a significant determinant of benefits to domestic demand, although the results suggest that it may provide some gain once GDP per capita is taken into account (See Figure 1). ${ }^{17}$ In sum, while production of IT goods (when correctly measured) has provided significant output benefits to producers, the welfare-enhancing benefits to real domestic demand go largely to users.

\section{Welfare Benefits of Falling Relative Prices of IT Goods}

We now turn to our second, and more direct, method of quantifying the welfare gains associated with productivity gains in the IT sector. ${ }^{18}$ The focus of this section is on the accumulated welfare benefits of the decline in prices of IT goods using the concept of "social

\footnotetext{
17 The coefficient on a regression of gains in terms of real domestic demand growth on gains in real GDP growth is small (0.02, with a t-ratio of 1.4$)$ and becomes completely insignificant once Singapore, which is an outlier in terms of IT production, is excluded (0.01, with a t-ratio of 0.3). When GDP per capita is included in the regression excluding Singapore, the coefficient of the gain in GDP growth rises $(0.03$, with a tratio of 1.4$)$, while the coefficient of GDP per capita is 0.0014 (t-ratio: 3.4 ).

18 This general approach has already been used to estimate the benefits from IT in the United States on macroeconomic and microeconomic data, e.g. by Brynjolfsson (1996) and Hitt and Brynjolfsson (1996).
} 
saving," which is a simple variation on consumer surplus used in the economic history literature on the welfare benefits of past waves of technological innovation. ${ }^{19}$

The gains in social saving owing to technological progress in the IT sector are represented by the area between the initial and the final price under the demand curve for products created by the new technology (see Figure 2). Unlike the consumer surplus, social saving includes intermediate spending by other producers (for example, freight transportation for the railroads, provision of electrical power to factories, or computers for firms) as well as by consumers. As the benefits from falling prices accrue to the purchasers of goods, not the producers, it is important to focus on the location of the buyers of the goods, rather than where they are produced. This is particularly relevant for highly traded goods, whereas the distinction is much less important if the output industry embodying the general purpose technology is largely non-traded, as in the case of electricity generation or railway transportation. A historical parallel of a technological revolution whose products were highly traded is cotton textiles, where the relative price fell more than six-fold between 1770 and 1841, and about half the British production was exported abroad (Harley, 1998). As a result, Harley (1999) estimates that the welfare benefits to Britain to be about 12 percent of 1841 income, with an approximately equal benefit (in value) to the rest of the world.

If there is perfect competition in IT production, then all of the surplus from IT production is reflected in falling prices. As the purchaser of an IT goods realizes one dollar in expected benefits as its price falls by one dollar, then the area under the demand curve provides an accurate measure of the benefits being provided by the IT sector. ${ }^{20}$ Indeed, if perfect competition is also present in the rest of the economy, then the benefits will eventually accrue to consumers. In the calculations below, the benefits from purchases of IT equipment by firms are assumed to be realized in the country in which the IT equipment is bought. If the gains from purchasing IT equipment are incorporated into final goods that are exported elsewhere, the welfare benefits will accrue in the other country. However, while IT goods themselves are highly traded, the assumption that the benefits largely accrue

\footnotetext{
${ }^{19}$ See Crafts (2000) for a comparison of this approach with the production function approach discussed above. Fogel (1964) is the classic reference for the railroads. In the historical literature, the social saving calculations generally do not account for the downward slope of the demand curve. By contrast, the results reported below are derived from elasticities associated with an estimated demand curve.

20 This assumes that the purchaser's marginal benefits from additional spending are not affected by this change in the budget constraint.
} 
domestically appears reasonable given the relatively closed nature of many of the countries and regions being analyzed (such as the United States and Japan) and the importance of IT spending to service industries, where trade ratios tend to be low.

The assumption that the IT industry is subject to perfect competition is sufficiently important to be worth discussing in more detail. In a less competitive environment, the benefits of higher productivity could be captured by producers through higher profits (i.e. excess returns) or wages. In terms of profits, some individual companies in the new technology sector have made high levels of profits. However, such star performers are offset by lower profits of other companies whose innovations are less successful and by new entrants, just as in any other competitive industry. Evidence from past large technological innovations indicates that no excess profits were made, ${ }^{21}$ and the highly competitive environment facing most IT companies makes it unlikely that such profits are being made currently, or at least that any such benefits are large in proportion to the fall in prices caused by competition. ${ }^{22}$ Similar observations relate to wages, where, it should be noted, a significant part of compensation was paid in terms of share options, which do not involve a direct rise in current expenses.

Among the many advantages of the social saving calculation is its simplicity. As the supply of IT goods expands at a rapid rate, it is reasonable to assume that the path of real output and prices in the IT sector can be used to calculate the demand curve for such products (once account is taken of rises in demand due to networking benefits by using time dummies). As is discussed later, this means that the demand curve can be identified using nominal spending on IT goods, their hedonic prices, and other series such as real GDP. Unlike the production function calculations discussed above, there is no need to make assumptions about such issues as depreciation rates of the IT capital stock, value added ratios, chain weighting, or the measurement of final output in industries such as financial services, which pose numerous methodological difficulties. As long as individuals/firms make rational purchasing decisions, the eventual benefits of such purchases are measured by the difference between current prices and the demand curve - i.e. social saving.

The analysis of changes in the social surplus offered here differs from the analysis of the impact of the IT sector on real domestic demand growth above in several aspects: (1)

\footnotetext{
${ }^{21}$ See Crafts (2000) and Brookes and Wahhaj (2000).

${ }^{22}$ International Monetary Fund (2001) contains more on the financial consequences of the IT revolution.
} 
most directly, the social surplus - unlike changes in the rate of growth - represents the impact of falling prices of IT goods accumulated over a period of time; (2) in estimating the social surplus, we control for the effect of changes in GDP on the demand for IT goods; (3) as detailed below, we use the WITSA database for nominal spending on IT goods, covering a larger number of countries.

\subsection{Empirical estimates}

The social saving calculation discussed above requires data on gross nominal spending on IT goods, price deflators, real GDP, and assumptions about the demand curve. If the demand curve has constant elasticities, it can be written as:

$$
\frac{E_{I T, t}}{P_{I T, t}}=\alpha \cdot\left(\frac{P_{I T, t}}{P_{G D P, t}}\right)^{-\beta} \cdot\left(\frac{G D P_{t}}{P_{G D P, t}}\right)^{-y} R G D P_{t}^{\gamma}=\alpha \cdot p_{I T, t}^{-\beta} \cdot R G D P_{t}^{\gamma},
$$

where $E_{I T}$ is nominal per capita expenditure on IT goods, $P_{I T}$ is a price index for IT goods, $P_{G D P}$ is the GDP deflator, GDP stands for nominal GDP per capita, alpha is a constant term (made time varying in the calculations to take account of rising demand from networking benefits i.e. the effect that as more people have IT equipment the benefits increase), and $\beta$ and $\gamma$ are the price and income elasticities of the demand for IT goods, respectively. We are interested in the welfare gains from the fall in prices of IT-related goods over some specified period (say, between year 0 and year 1), evaluated at year 1. For our specification, this means that we are conditioning on real GDP for year 1. Using standard integration techniques, the increase in social saving between year 0 and year 1 , owing to a fall in relative prices of IT goods, is:

$$
\Delta S S=\alpha R G D P_{t}^{\gamma} \cdot \int_{p_{T T, 1}}^{p_{\Pi T} 0} s^{-\beta} d s=\frac{\alpha \cdot R G D P_{t}^{\gamma}}{1-\beta}\left(p_{I T, 0}^{1-\beta}-p_{I T, 1}^{1-\beta}\right),
$$

The increase in social savings is larger for a higher level of real GDP (provided that the income elasticity $\gamma$ is positive), a larger decline in the relative price of IT goods, a higher price elasticity of demand $\beta$ ), and, other things equal, larger demand for IT products (parameter $\alpha$ ). 


\section{Data issues}

Separate calculations are reported below for IT hardware (comprising computers and peripheral equipment), software spending, and communication equipment. The data on nominal spending on IT goods come from WITSA, a trade group associated with the IT industry which collects data across countries in a homogenous manner. While the Reed database was used earlier because it includes data on both production and sales, the WITSA data (which does not include production) is preferable for this exercise due to its wider range of countries (around 50) and better data on sales. In what follows, we use a sample of 41 countries, which excludes from the full set of countries covered by WITSA nine transition economies whose data are likely to be contaminated by structural change. ${ }^{23}$

Compared to using national account data across individual countries, the WITSA data have two advantages: because they are homogenously collected they do not have the idiosyncrasies observed in IT data across national sources (such as significant differences in the ratio of gross spending to value added - see Deutsche Bank, 2001); and they focus on the theoretically correct concept of gross IT spending, rather than value added which is needed in the national account data to avoid double counting across the whole economy.

The WITSA data cover the years 1992-99, dividing ICT spending into a range of components: telecommunications, hardware, software, internal ICT spending, and ICT service spending. For the purposes of social welfare calculations, it is necessary to map these data into spending on three types of goods for which there are hedonic price deflators, namely computers and peripheral equipment, software, and communications equipment. Based on a comparison between the WITSA data and national account information on IT spending in both the United States and France, gross spending on computers and peripheral goods is assumed to equal the WITSA data on hardware spending, while spending on communications equipment is assumed to comprise 30 percent of overall telecommunications equipment (these assumptions ae also made in Schreyer, 2000). For software, gross spending is

\footnotetext{
${ }^{23}$ The group comprises 18 countries that include the largest 12 producers and consumers Australia, Brazil, Canada, France, Germany, Ireland, Italy, Japan, Korea, Malaysia, the Netherlands, Singapore, Sweden, Switzerland, Taiwan Province of China, Thailand, the United Kingdom, and the United States (used later as a check on the estimation results) plus Argentina, Austria, Belgium, Chile, China (PRC), Colombia, Denmark, Egypt, Finland, Greece, Hong Kong (SAR), India, Indonesia, Israel, Mexico, New Zealand, Norway, Philippines, Portugal, South Africa, Spain, Turkey, and Venezuela.
} 
assumed to be double the WITSA series on such spending, as spending on in-house software programming (which is included in the national accounts data from which the hedonic price indices are derived) is likely to be included in WITSA's internal ICT spending. As discussed in Section 3, the (hedonic) price indices for IT goods across countries are calculated based on those used in the US NIPA, adjusted by exchange rate changes.

The relevant income and price elasticities were estimated using a panel regression from 1992 to 1999 with fixed time dummies and country effects, with the following specification:

$$
\ln \left(\frac{E_{I T, i t}}{P_{I T, i t}}\right)=\alpha_{i}-\beta \ln \left(\frac{P_{I T, i t}}{P_{G D P, i t}}\right)+\gamma \ln \left(R G D P_{i t}\right)+\delta_{t}+\varepsilon_{i t},
$$

where $i$ indexes countries, $t$ indicated time periods, and the respective variables are defined as for Eq. 4, above. Time dummies were used to account for autonomous changes in demand associated with network benefits associated with diffusion of users and information on the capabilities of the new technology. The specification uses OLS, which is appropriate if the changes in underlying price changes are being driven entirely by supply-side changes. This seems a reasonable approximation given the rapid changes in technology and competitive nature of the sector. Hitt and Brynjolfsson (1996) find that using more sophisticated econometric techniques makes little difference for IT calculations of this type.

The results are reported in Table 5, and indicate price elasticities of between -0.9 (for telecommunications equipment) and -1.3 (for hardware), estimates that are similar to those generated by Brynjolfsson and Hitt (1995). The income elasticities, estimated between 1.2 and 1.8, are generally significantly larger than one, indicating that IT products are superior goods. $^{24}$

Given the importance of these coefficients for the calculations, the elasticities were reestimated using two other samples, first a group of 18 countries, which includes the 12 largest consumers and the 12 largest producers of IT goods, where the data may be assumed to be the most reliable, and second official NIA data for two countries where such information is readily available, namely the United States and France (Tables 6 and 7). The results for the group of 18 countries tend to find somewhat smaller (absolute) values of the price and income elasticities, although in the coefficient that matters most in the calculations

\footnotetext{
${ }^{24}$ Hitt and Brinjolfsson (1996) find elasticities of around 1 for a cross-sectional regression across US industries.
} 
— the absolute value of the price elasticity of hardware - the differences are relatively small (1.13 versus 1.31). The opposite tendency is true of the regressions on individual country data - absolute values of the elasticities tend to be larger. This is particularly true of the income elasticities, reflecting the absence of time dummies that model autonomous rises in demand for IT equipment. In the case of the most critical parameter - the absolute value of the price elasticity for hardware — the elasticities are higher, ranging from 1.49-1.79. In short, these calculations find a range of values for this critical elasticity of 1.1-1.8, with the calculation based on the full panel of 41 countries producing a "reasonable" value of 1.3. Accordingly, this is the value used in the calculations. ${ }^{25}$

The welfare gains over 1992-99 for all 41 countries are reported in Tables 8 and 9, with the benefits being calculated based on the fitted level of expenditure on hardware, software, and communications equipment for 1999, and the fall in relative prices of the respective category of IT expenditure over 1992-99. The change in relative prices reported in Table 8 is based on a weighted geometric average of the respective price indices. Table 8 also provides an estimate of the gain in social saving for the period 1985-2001. While the WITSA dataset (on which the estimated demand curves are based) extends from 1992-99, Equation 5 can be used to obtain estimates of the change in social saving for longer periods, provided that the change in relative prices of IT goods is known.

The following results stand out:

Benefits are loosely associated with income per capita. As countries near the technological barrier are the most likely to be in the vanguard in adopting IT, current social saving benefits would be expected to be related to income per capita. As Figure 3 shows, this relationship is broadly true, but there is also a lot of individual country variance.

The social saving benefits are not closely connected to the size of IT production in a country. Some of the major beneficiaries have small domestic IT sectors (such as Australia

\footnotetext{
${ }^{25}$ Using a price elasticity of 1.1 (or 1.8) for IT hardware in the US, rather than an elasticity of 1.3, we obtain estimates of the social surplus (hardware only) that are 17 percent lower (or 63 percent higher), with a similar effect for other countries in the sample. As a further sensitivity check, we have also calculated the social surplus using a Hicksian demand function. The results are very similar to the ones presented here; for IT hardware, estimates of the social surplus based on a Hicksian compensated demand function are about 1-2 percent (not percentage points) higher across countries.
} 
and New Zealand), while other countries which are major producers of IT equipment are not experiencing major social saving gains (such as Malaysia, Thailand, and the Philippines). ${ }^{26}$

While the largest social gains are in the United States, several other countries also have significant benefits. The social saving gains in the United States are estimated at around 4 percent of GDP over the 1992-99 period, rising to 5.6 percent of GDP for 1985-2001. However, a range of other countries — Singapore, New Zealand, Australia, and the United Kingdom - have social saving gains that are over 80 percent the size, in terms of GDP, of those accruing to the United States during 1992-99.

Social saving gains in many euro-area members are currently relatively small. The social saving benefits are only about 50 percent of the United States value, in terms of GDP, for Germany, Austria, and France, and about a third for Italy and Greece, compared with 70 percent or more for other Europeans countries such as Sweden, Denmark, the Netherlands, Ireland, Finland, and the United Kingdom.

The main component of gains in social saving is expenditure on hardware. As Table 9 shows, about 60 percent of the gains from IT investment, on average, come from hardware, largely reflecting larger decreases in relative prices.

For countries with lower overall IT expenditure, the share of telecommunications in overall IT expenditure tends to be higher. However, owing to a smaller decline in relative prices for telecommunications equipment (compared with computer hardware), their contribution to the overall social surplus is relatively smaller.

The estimated benefits for the United States and several other countries since 1985 (and even 1992) are already significant compared to the overall benefits for the leading countries of some earlier "all-purpose" technological revolutions, such as the railways or electricity. For example, the overall benefits of the railways are estimated to have been at about 10 percent of GDP for England and Wales and 5-10 percent for the United States. This reflects the more rapid accrual of benefits in the IT revolution compared with earlier technological revolutions (Crafts, 2001).

\footnotetext{
${ }^{26}$ Similar to the results found in Section 3.
} 


\section{Summary and Conclusions}

This paper analyzes the macroeconomic impact of falling prices of IT goods on welfare from two different angles. First, following an approach similar to earlier growth-accounting studies, but expanding the work to look at both real GDP and real domestic demand, we find that while IT sectors have provided substantial output benefits to those countries with large production sectors, most of the demand-side benefits have been transferred to importing countries through changes in the terms of trade. For example, some of the major producers of IT goods (Malaysia, Ireland) experience only average gains in terms of the growth rate of real domestic demand, while Australia, with little production of IT-related goods, is among the principal gainers.

Second, we estimate the social savings associated with falling prices of IT goods. Social saving, a generalization of consumer surplus, has been used in the economic history literature to estimate the welfare benefits of earlier waves of technological innovation. We again find that the benefits of IT use are not closely correlated with the sze of the ITproducing sector in an economy. Our results also indicate that the gains in social saving are substantial. For the period 1985-2001, the fall in the prices of IT goods is associated with social savings of 5 percent of GDP or more for the United States, Singapore, New Zealand, and Australia. This means that social saving gains associated with IT already are a significant proportion of the gains from some earlier general-purpose technological revolutions such as railways.

The observation that the main benefits of IT accrue to users rather than producers is important for at least two reasons. First, it suggest that while earlier work focusing on the benefits of IT in terms of output is useful in assessing the size of gains associated with the IT revolution, it tells only part of the story and fails to illustrate how the benefits of this production are distributed across countries (the focus of this study) or within a country (where the IT sector reaps little benefit from technological innovation, again owing to falling relative prices). Second, while this study is limited to an analysis of the direct benefits of falling relative prices, the productivity spillovers to the rest of the economy as production techniques are reorganized also depend upon use, not production, further underlining our central message. 
Table 1. Changes in Relative Prices of IT Goods for the United States (Accumulated change over the period indicated, in percent)

\begin{tabular}{llll}
\hline & $1985-92$ & $1992-2001$ & $1985-2001$ \\
\hline Computers and peripheral equipment & -64.4 & -87.9 & -95.7 \\
Software & -26.7 & -20.1 & -41.1 \\
Communication equipment & -18.9 & -32.9 & -45.6 \\
Digital integrated circuits & -48.6 & -77.6 & -88.5 \\
Microprocessors & -33.1 & -99.3 & -99.6 \\
\hline
\end{tabular}

Source: Authors' calculations, based on data from US Bureau of Economic Analysis, National Income and Product Account Tables, and from the Bureau of Labor Statistics, Producer Price Indices (for integrated circuits and microprocessors).

Table 2. Contribution of IT to Acceleration in Productivity Growth in the United States

\begin{tabular}{|c|c|c|c|c|}
\hline & Gordon, 2002 & $\begin{array}{c}\text { U.S. } \\
\text { CEA, } 2001\end{array}$ & $\begin{array}{c}\text { Jorgenson and } \\
\text { Stiroh, } 2000\end{array}$ & $\begin{array}{l}\text { Oliner and } \\
\text { Sichel, } 2000\end{array}$ \\
\hline Period under study & $1995-2000$ & $1995-2000$ & 1995-1999 & 1995-1999 \\
\hline Acceleration & 1.44 & 1.63 & 0.95 & 1.16 \\
\hline \multicolumn{5}{|l|}{ Capital deepening } \\
\hline IT-related & 0.60 & 0.62 & 0.34 & 0.50 \\
\hline Other & -0.23 & -0.23 & -0.05 & -0.17 \\
\hline Labor Quality & 0.01 & 0.00 & 0.01 & 0.04 \\
\hline \multicolumn{5}{|l|}{ TFP } \\
\hline IT -related & 0.30 & 0.18 & 0.24 & 0.31 \\
\hline Other & 0.22 & 1.00 & 0.41 & 0.49 \\
\hline Contribution of Price Measurement & 0.14 & n.a. & n.a. & n.a. \\
\hline Cyclical Effect & 0.40 & 0.04 & n.a. & n.a. \\
\hline
\end{tabular}

Sources: See References. 
Table 3. The Impact of the IT Sector on Real GDP Growth, 1996-2000

\begin{tabular}{|c|c|c|c|c|}
\hline & $\begin{array}{c}\text { IT } \\
\text { production } \\
\text { (share of } \\
\text { GDP, } \\
2000 \text { ) }\end{array}$ & $\begin{array}{l}\text { Relative } \\
\text { price of IT } \\
\text { products } \\
\text { (annual } \\
\text { rate of } \\
\text { growth) }\end{array}$ & $\begin{array}{l}\text { IT } \\
\text { production } \\
\text { (annual rate } \\
\text { of growth) }\end{array}$ & $\begin{array}{c}\text { Impact of IT } \\
\text { productivity } \\
\text { gains } \\
\text { (contribution } \\
\text { to GDP } \\
\text { growth) }\end{array}$ \\
\hline Australia & 0.2 & -9.0 & 2.0 & 0.03 \\
\hline Austria & 0.6 & -5.7 & 13.5 & 0.03 \\
\hline Belgium & 1.4 & -7.7 & 12.8 & 0.10 \\
\hline Brazil & 1.1 & -14.5 & 23.1 & 0.17 \\
\hline Canada & 0.8 & -12.5 & 17.8 & 0.10 \\
\hline Denmark & 0.5 & 3.6 & 21.6 & -0.01 \\
\hline Finland & 5.3 & 2.5 & 19.8 & -0.09 \\
\hline France & 1.5 & -4.9 & 14.0 & 0.06 \\
\hline Germany & 1.1 & -4.6 & 16.3 & 0.04 \\
\hline Greece & 0.3 & -4.7 & 16.5 & 0.01 \\
\hline Hong Kong (SAR) & 1.1 & -15.8 & 18.5 & 0.20 \\
\hline India & 0.2 & -11.0 & 9.4 & 0.04 \\
\hline Indonesia & 2.0 & -8.5 & 45.0 & 0.17 \\
\hline Ireland & 14.2 & -18.1 & 48.1 & 2.10 \\
\hline Israel & 3.2 & -10.1 & 30.7 & 0.27 \\
\hline Italy & 0.8 & -10.8 & 13.0 & 0.09 \\
\hline Japan & 2.6 & -12.8 & 17.4 & 0.37 \\
\hline Korea & 9.7 & -10.4 & 32.4 & 0.85 \\
\hline Malaysia & 31.5 & -15.0 & 47.8 & 3.31 \\
\hline Netherlands & 1.0 & -12.2 & 13.6 & 0.13 \\
\hline Norway & 0.4 & -5.9 & 5.8 & 0.03 \\
\hline Philippines & 11.7 & -15.4 & 54.7 & 1.13 \\
\hline Portugal & 0.5 & -13.8 & 16.5 & 0.07 \\
\hline Singapore & 39.2 & -17.6 & 34.4 & 6.71 \\
\hline South Africa & 0.3 & 6.4 & -3.8 & -0.01 \\
\hline Spain & 0.7 & -5.0 & 13.9 & 0.03 \\
\hline Sweden & 4.3 & 2.7 & 20.1 & -0.10 \\
\hline Switzerland & 0.5 & -5.2 & 6.8 & 0.03 \\
\hline Taiwan Province of China & 8.9 & -19.2 & 44.9 & 1.50 \\
\hline Thailand & 8.2 & -15.3 & 42.4 & 0.96 \\
\hline United Kingdom & 2.0 & -16.2 & 28.1 & 0.30 \\
\hline United States & 1.8 & -15.1 & 27.5 & 0.28 \\
\hline
\end{tabular}


Table 4. The Impact of the IT Sector on the Growth Rate of Real Domestic Demand, 1996-2000

\begin{tabular}{|c|c|c|c|c|}
\hline & $\begin{array}{c}\text { IT } \\
\text { expenditure } \\
\text { (share of } \\
\text { GDP, 2000) }\end{array}$ & $\begin{array}{l}\text { IT expenditure } \\
\text { (real annual } \\
\text { rate of growth) }\end{array}$ & $\begin{array}{c}\text { Price index for } \\
\text { IT expenditure } \\
\text { (annual rate of } \\
\text { growth) }\end{array}$ & $\begin{array}{l}\text { Impact of IT } \\
\text { productivity gains } \\
\text { (contribution to } \\
\text { change in demand } \\
\text { growth) }\end{array}$ \\
\hline Australia & 1.8 & 29.4 & -15.6 & 0.25 \\
\hline Austria & 1.8 & 26.9 & -9.7 & 0.12 \\
\hline Belgium & 2.0 & 21.2 & -8.2 & 0.13 \\
\hline Brazil & 1.2 & 31.6 & -11.2 & 0.10 \\
\hline Canada & 1.6 & 32.5 & -17.8 & 0.28 \\
\hline Denmark & 1.8 & 26.7 & -13.3 & 0.21 \\
\hline Finland & 1.6 & 26.7 & -12.8 & 0.21 \\
\hline France & 1.7 & 19.1 & -7.7 & 0.11 \\
\hline Germany & 1.6 & 23.6 & -10.3 & 0.12 \\
\hline Greece & 1.3 & 19.9 & -6.0 & 0.05 \\
\hline Hong Kong (SAR) & 1.3 & 20.8 & -15.3 & 0.20 \\
\hline India & 0.4 & 24.9 & -16.7 & 0.08 \\
\hline Indonesia & 0.8 & 1.6 & -2.7 & 0.01 \\
\hline Ireland & 1.4 & 27.9 & -12.9 & 0.20 \\
\hline Israel & 1.3 & 25.2 & -16.5 & 0.21 \\
\hline Italy & 1.3 & 19.8 & -10.1 & 0.11 \\
\hline Japan & 1.2 & 20.4 & -13.6 & 0.17 \\
\hline Korea & 3.0 & 22.0 & -9.2 & 0.28 \\
\hline Malaysia & 1.4 & 16.4 & -10.7 & 0.21 \\
\hline Netherlands & 1.9 & 26.2 & -11.3 & 0.19 \\
\hline Norway & 1.6 & 23.5 & -12.9 & 0.22 \\
\hline Philippines & 1.3 & 15.7 & -7.9 & 0.09 \\
\hline Portugal & 1.3 & 20.6 & -10.7 & 0.11 \\
\hline Singapore & 2.7 & 24.6 & -10.3 & 0.30 \\
\hline South Africa & 2.4 & 26.8 & -9.8 & 0.19 \\
\hline Spain & 1.7 & 28.3 & -8.0 & 0.09 \\
\hline Sweden & 2.4 & 20.9 & -12.6 & 0.31 \\
\hline Switzerland & 2.1 & 24.2 & -10.2 & 0.18 \\
\hline Taiwan Province of China & 1.0 & 35.6 & -15.4 & 0.15 \\
\hline Thailand & 1.0 & 15.2 & -9.9 & 0.10 \\
\hline United Kingdom & 2.1 & 28.3 & -16.3 & 0.31 \\
\hline United States & 2.4 & 31.5 & -16.7 & 0.39 \\
\hline
\end{tabular}

Source: Author's calculation. 
Table 5. Estimated Demand Elasticities for the Sample Including 41 Countries

\begin{tabular}{llll}
\hline & \multicolumn{1}{c}{$\begin{array}{c}\text { Price } \\
\text { elasticity }\end{array}$} & $\begin{array}{c}\text { Income } \\
\text { elasticity }\end{array}$ & \multicolumn{1}{c}{$R^{2}$} \\
\hline Hardware & 1.31 & 1.58 & 0.995 \\
& $(15.7)$ & $(10.1)$ & \\
Software & 1.05 & 1.84 & 0.994 \\
Telecommunications equipment & $(9.8)$ & $(9.1)$ & \\
& 0.87 & 1.21 & 0.987 \\
& $(7.8)$ & $(5.7)$ & \\
\hline
\end{tabular}

Notes: $t$-ratios in parentheses.

Table 6. Estimated Demand Elasticities for the Sample Including 18 Countries

\begin{tabular}{lccc}
\hline & $\begin{array}{c}\text { Price } \\
\text { elasticity }\end{array}$ & $\begin{array}{c}\text { Income } \\
\text { elasticity }\end{array}$ & $R^{2}$ \\
\hline Hardware & 1.13 & 1.53 & $(7.1)$ \\
Software & $(9.0)$ & 1.62 & 0.993 \\
& 0.71 & $(6.2)$ & 0.991 \\
Telecommunications equipment & $(4.6)$ & 0.68 & 0.981 \\
\hline Notes: $t$-ratios in parentheses. & 0.58 & $(2.43)$ &
\end{tabular}

Notes: $t$-ratios in parentheses.

Table 7. Estimated Elasticities for the United States and France, $1980-99$

\begin{tabular}{llll}
\hline & $\begin{array}{l}\text { Price } \\
\text { Elasticity }\end{array}$ & $\begin{array}{l}\text { Income } \\
\text { elasticity }\end{array}$ & $R^{2}$ \\
United States & & & \\
Hardware & 1.79 & 3.23 & 1.00 \\
& $(9.5)$ & $(10.3)$ & 1.00 \\
Software & 1.52 & 2.40 & \\
& $(3.8)$ & $(5.2)$ & 1.00 \\
Telecommunications equipment & 2.75 & 4.1 & \\
& $(6.3)$ & $(8.2)$ & \\
France & & & \\
Hardware & 1.49 & 2.75 & 1.00 \\
Software & $(7.9)$ & $(9.4)$ & 1.00 \\
Telecommunications equipment & 0.6 & 1.44 & \\
& $(2.1)$ & $(4.5)$ & \\
& 3.3 & 4.6 & $(17.9)$ \\
\hline
\end{tabular}

Notes: $t$-ratios in parentheses. A time trend was included in the regressions. 
Table 8. ITC Expenditure and Social Saving

\begin{tabular}{|c|c|c|c|c|c|}
\hline & \multicolumn{2}{|c|}{$\begin{array}{l}\text { Expenditure on ITC } \\
\text { goods, } 1999 \\
\text { (In percent of GDP) }\end{array}$} & \multirow{2}{*}{$\begin{array}{l}\text { Change in relative } \\
\text { price of ITC goods, } \\
1992-99 \\
\text { (In percent) }\end{array}$} & \multirow[t]{2}{*}{$\begin{array}{l}\text { Change in Social } \\
\text { Saving, 1992-99 } \\
\text { (In percent of GDP) }\end{array}$} & \multirow[t]{2}{*}{$\begin{array}{l}\text { Change in Social } \\
\text { Saving, 1985-2001 } \\
\text { (In percent of GDP) }\end{array}$} \\
\hline & actual & fitted & & & \\
\hline Argentina & 1.6 & 1.7 & -46.0 & 1.3 & 1.3 \\
\hline Australia & 4.1 & 4.3 & -48.7 & 3.6 & 5.0 \\
\hline Austria & 2.6 & 2.7 & -49.0 & 2.0 & 2.7 \\
\hline Belgium & 3.4 & 3.2 & -45.2 & 2.3 & 3.0 \\
\hline Brazil & 3.4 & 2.1 & -53.2 & 1.8 & 2.1 \\
\hline Canada & 3.9 & 3.7 & -46.1 & 2.8 & 4.0 \\
\hline Chile & 2.7 & 2.5 & -53.5 & 2.2 & 2.7 \\
\hline China (PRC) & 2.2 & 2.1 & -63.2 & 2.0 & 2.4 \\
\hline Colombia & 3.5 & 2.2 & -62.5 & 2.1 & 2.3 \\
\hline Denmark & 3.5 & 3.5 & -53.6 & 2.9 & 4.0 \\
\hline Egypt & 1.0 & 1.3 & -68.5 & 1.1 & 1.0 \\
\hline Finland & 3.3 & 3.3 & -52.0 & 2.7 & 3.8 \\
\hline France & 2.7 & 2.8 & -47.7 & 2.1 & 2.7 \\
\hline Germany & 3.0 & 2.8 & -48.0 & 2.1 & 2.8 \\
\hline Greece & 1.8 & 1.7 & -49.8 & 1.3 & 1.3 \\
\hline Hong Kong (SAR) & 3.1 & 3.1 & -59.5 & 3.0 & 3.6 \\
\hline India & 1.3 & 1.4 & -52.3 & 1.1 & 1.1 \\
\hline Indonesia & 0.9 & 1.3 & -45.1 & 1.0 & 0.9 \\
\hline Ireland & 2.5 & 3.1 & -55.4 & 2.7 & 3.6 \\
\hline Israel & 3.5 & 3.6 & -55.8 & 3.2 & 4.2 \\
\hline Italy & 2.0 & 2.2 & -40.1 & 1.5 & 1.9 \\
\hline Japan & 2.8 & 2.9 & -58.6 & 2.6 & 3.4 \\
\hline Korea & 2.8 & 3.4 & -56.6 & 3.2 & 4.4 \\
\hline Malaysia & 3.1 & 3.1 & -46.3 & 2.5 & 3.4 \\
\hline Mexico & 1.4 & 1.9 & -56.4 & 1.6 & 1.8 \\
\hline Netherlands & 3.9 & 3.7 & -49.2 & 2.8 & 3.9 \\
\hline New Zealand & 4.8 & 4.5 & -51.0 & 3.9 & 5.1 \\
\hline Norway & 3.1 & 3.4 & -52.8 & 2.7 & 3.8 \\
\hline Philippines & 1.5 & 1.8 & -59.1 & 1.5 & 1.7 \\
\hline Portugal & 2.3 & 2.2 & -52.5 & 1.8 & 2.1 \\
\hline Singapore & 4.4 & 4.4 & -54.3 & 4.0 & 5.4 \\
\hline South Africa & 3.9 & 3.3 & -47.8 & 2.6 & 3.7 \\
\hline Spain & 1.9 & 2.2 & -39.8 & 1.6 & 2.0 \\
\hline Sweden & 4.0 & 4.1 & -44.6 & 3.2 & 4.7 \\
\hline Switzerland & 4.3 & 3.9 & -50.1 & 3.1 & 4.2 \\
\hline Taiwan Province of China & 2.4 & 2.3 & -47.2 & 1.9 & 2.4 \\
\hline Thailand & 1.5 & 1.8 & -50.0 & 1.4 & 1.6 \\
\hline Turkey & 2.0 & 1.6 & -49.1 & 1.3 & 1.4 \\
\hline United Kingdom & 3.6 & 4.1 & -54.9 & 3.5 & 4.8 \\
\hline United States & 4.2 & 4.5 & -58.3 & 4.1 & 5.6 \\
\hline Venezuela & 1.7 & 2.0 & -72.4 & 2.0 & 2.3 \\
\hline
\end{tabular}

Source: Authors' calculations. 
Table 9. Decomposition of Social Saving

\begin{tabular}{|c|c|c|c|c|c|c|c|}
\hline & $\begin{array}{l}\text { Hardware } \\
\text { (In percent } \\
\text { of GDP) }\end{array}$ & $\begin{array}{l}\text { (In percent } \\
\text { of total) }\end{array}$ & $\begin{array}{l}\text { Software } \\
\text { (In percent } \\
\text { of GDP) }\end{array}$ & $\begin{array}{l}\text { (In percent } \\
\text { of total) }\end{array}$ & $\begin{array}{l}\text { Communica } \\
\text { Equipment } \\
\text { (In percent } \\
\text { of GDP) }\end{array}$ & $\begin{array}{l}\text { ions } \\
\text { (In percent } \\
\text { of total) }\end{array}$ & $\begin{array}{l}\text { Change in Social } \\
\text { Saving, 1992-99 } \\
\text { (In percent of GDP) }\end{array}$ \\
\hline Argentina & 0.4 & 29.7 & 0.0 & 0.8 & 0.9 & 69.6 & 1.3 \\
\hline Australia & 2.3 & 62.5 & 0.0 & 0.8 & 1.3 & 36.8 & 3.6 \\
\hline Austria & 1.2 & 58.6 & 0.0 & 1.1 & 0.8 & 40.3 & 2.0 \\
\hline Belgium & 1.3 & 59.2 & 0.0 & 1.7 & 0.9 & 39.0 & 2.3 \\
\hline Brazil & 0.9 & 48.7 & 0.0 & 2.5 & 0.9 & 48.8 & 1.8 \\
\hline Canada & 1.9 & 66.2 & 0.0 & -1.1 & 1.0 & 35.0 & 2.8 \\
\hline Chile & 1.1 & 48.8 & 0.0 & 1.9 & 1.1 & 49.3 & 2.2 \\
\hline China (PRC) & 1.1 & 57.1 & 0.0 & 0.5 & 0.8 & 42.5 & 2.0 \\
\hline Colombia & 1.0 & 47.2 & 0.1 & 3.1 & 1.0 & 49.8 & 2.1 \\
\hline Denmark & 1.9 & 67.2 & 0.1 & 1.9 & 0.9 & 31.0 & 2.9 \\
\hline Egypt & 0.4 & 34.1 & 0.0 & 4.6 & 0.6 & 61.3 & 1.1 \\
\hline Finland & 1.8 & 67.3 & 0.0 & 0.0 & 0.9 & 32.7 & 2.7 \\
\hline France & 1.2 & 56.9 & 0.0 & 0.7 & 0.9 & 42.3 & 2.1 \\
\hline Germany & 1.2 & 57.0 & 0.0 & 1.1 & 0.9 & 41.9 & 2.1 \\
\hline Greece & 0.3 & 26.0 & 0.0 & 1.8 & 1.0 & 72.2 & 1.3 \\
\hline Hong Kong (SAR) & 1.5 & 49.4 & 0.1 & 2.2 & 1.5 & 48.3 & 3.0 \\
\hline India & 0.4 & 35.6 & 0.0 & 0.6 & 0.7 & 63.8 & 1.1 \\
\hline Indonesia & 0.3 & 29.1 & 0.0 & -0.6 & 0.7 & 71.5 & 1.0 \\
\hline Ireland & 1.6 & 57.3 & 0.0 & 1.7 & 1.1 & 41.0 & 2.7 \\
\hline Israel & 1.9 & 60.6 & 0.1 & 4.5 & 1.1 & 34.9 & 3.2 \\
\hline Italy & 0.7 & 45.1 & 0.0 & -1.9 & 0.9 & 56.7 & 1.5 \\
\hline Japan & 1.6 & 60.4 & 0.1 & 2.1 & 1.0 & 37.5 & 2.6 \\
\hline Korea & 2.1 & 65.9 & 0.0 & -0.2 & 1.1 & 34.3 & 3.2 \\
\hline Malaysia & 1.5 & 57.4 & 0.0 & -0.8 & 1.1 & 43.4 & 2.5 \\
\hline Mexico & 0.7 & 42.9 & 0.0 & 1.6 & 0.9 & 55.5 & 1.6 \\
\hline Netherlands & 1.8 & 64.0 & 0.0 & 1.6 & 1.0 & 34.4 & 2.8 \\
\hline New Zealand & 2.3 & 59.0 & 0.2 & 4.1 & 1.4 & 36.9 & 3.9 \\
\hline Norway & 1.8 & 66.3 & 0.0 & 0.8 & 0.9 & 32.9 & 2.7 \\
\hline Philippines & 0.7 & 48.4 & 0.0 & 2.1 & 0.7 & 49.5 & 1.5 \\
\hline Portugal & 0.8 & 45.0 & 0.0 & 1.3 & 1.0 & 53.7 & 1.8 \\
\hline Singapore & 2.6 & 64.8 & 0.1 & 1.7 & 1.3 & 33.5 & 4.0 \\
\hline South Africa & 1.7 & 64.1 & 0.0 & -1.9 & 1.0 & 37.8 & 2.6 \\
\hline Spain & 0.8 & 47.6 & 0.0 & -2.2 & 0.9 & 54.7 & 1.6 \\
\hline Sweden & 2.3 & 71.0 & -0.1 & -3.1 & 1.0 & 32.1 & 3.2 \\
\hline Switzerland & 2.0 & 63.3 & 0.1 & 2.4 & 1.1 & 34.3 & 3.1 \\
\hline Taiwan Province of China & 0.9 & 47.3 & 0.0 & -0.3 & 1.0 & 53.0 & 1.9 \\
\hline Thailand & 0.6 & 47.2 & 0.0 & -0.4 & 0.7 & 53.2 & 1.4 \\
\hline Turkey & 0.5 & 36.2 & 0.0 & 0.0 & 0.8 & 63.8 & 1.3 \\
\hline United Kingdom & 2.4 & 67.3 & 0.2 & 4.8 & 1.0 & 27.9 & 3.5 \\
\hline United States & 2.8 & 69.7 & 0.2 & 5.3 & 1.0 & 25.1 & 4.1 \\
\hline Venezuela & 1.0 & 52.1 & 0.1 & 5.3 & 0.9 & 42.6 & 2.0 \\
\hline
\end{tabular}

Source: Authors' calculations. 


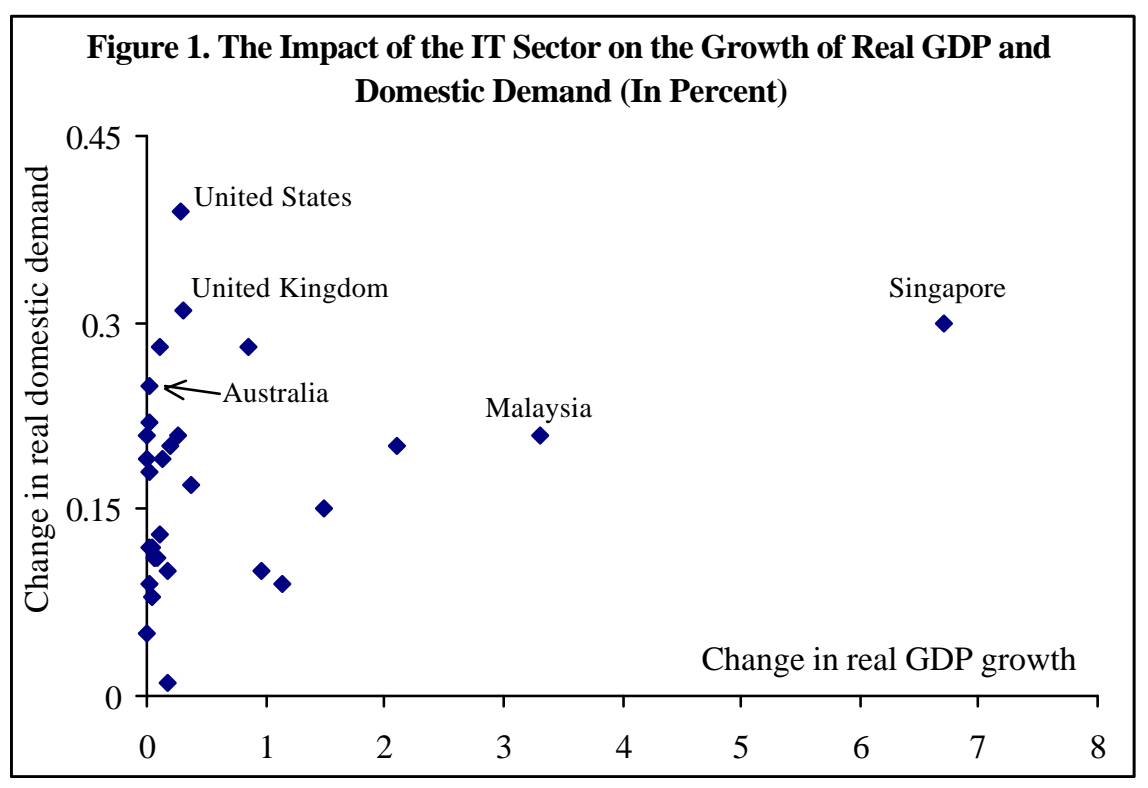

Figure 2. The Demand for IT Goods and the Social Saving

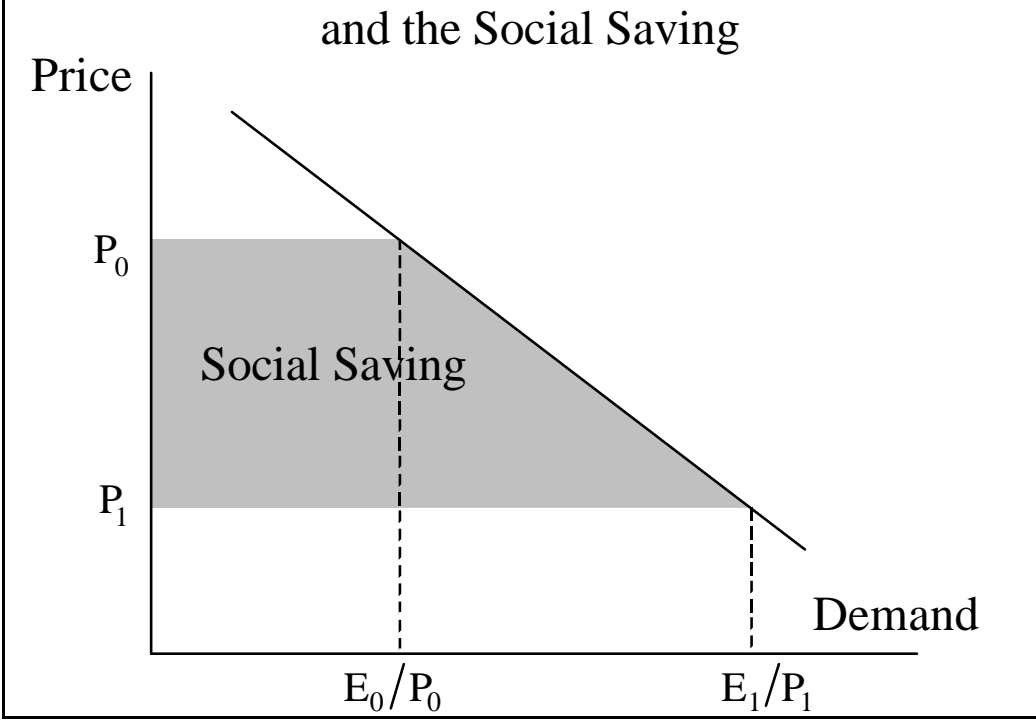




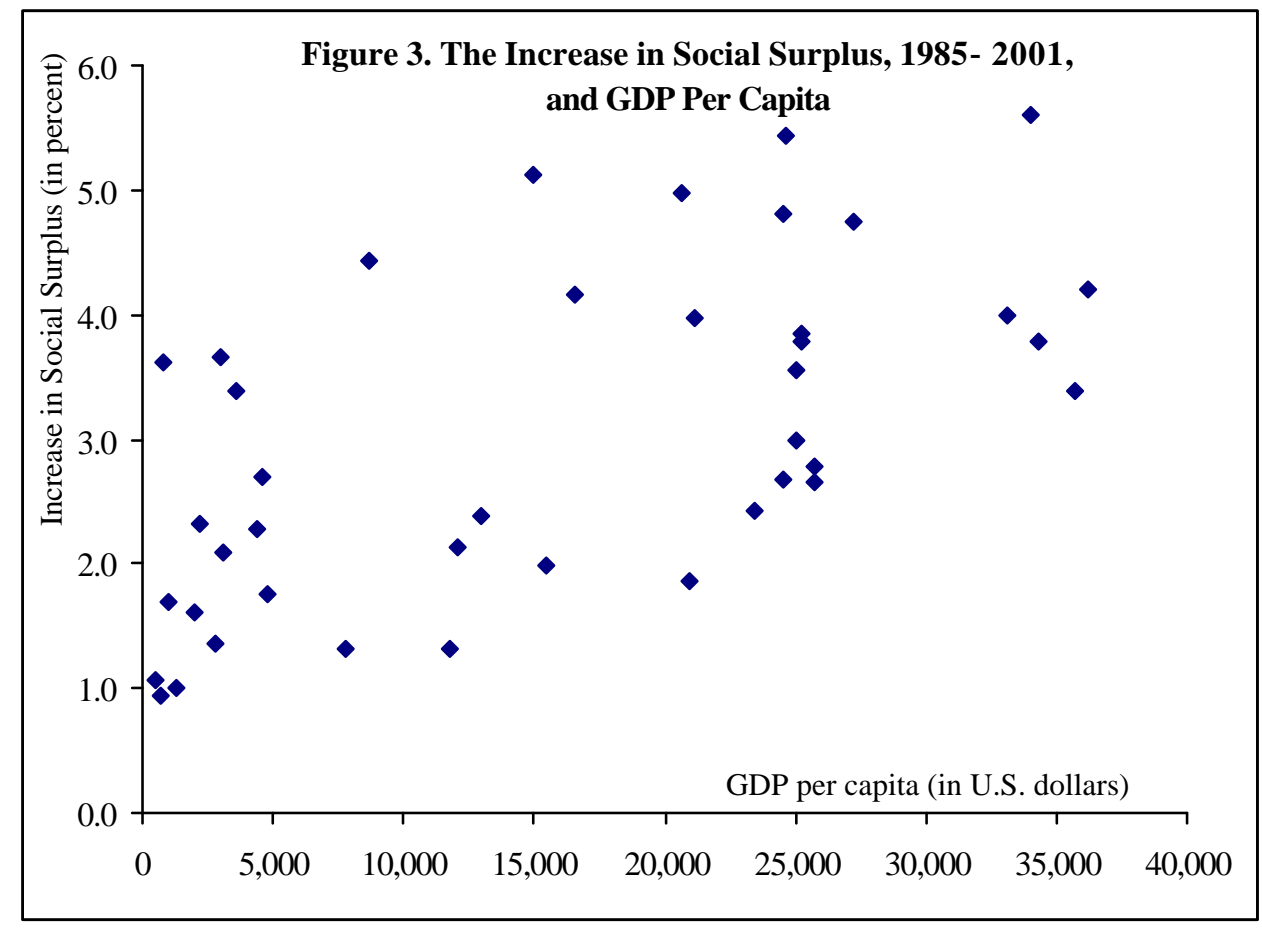




\section{Appendix}

Table A1. IT Production, 1996-2000

(avg. share of GDP, 1996-2000)

\begin{tabular}{|c|c|c|c|c|}
\hline & EDP goods & $\begin{array}{l}\text { Communications } \\
\text { Equipment }\end{array}$ & $\begin{array}{l}\text { Active Components } \\
\text { (net exports) }\end{array}$ & Sum \\
\hline Australia & 0.2 & 0.2 & -0.2 & 0.2 \\
\hline Austria & 0.3 & 0.3 & 0.0 & 0.5 \\
\hline Belgium & 0.8 & 0.6 & -0.2 & 1.2 \\
\hline Brazil & 1.1 & 0.2 & -0.2 & 1.1 \\
\hline Canada & 0.6 & 0.5 & -0.4 & 0.7 \\
\hline Denmark & 0.1 & 0.4 & -0.1 & 0.3 \\
\hline Finland & 0.7 & 4.0 & -0.8 & 3.8 \\
\hline France & 0.5 & 0.8 & -0.1 & 1.3 \\
\hline Germany & 0.4 & 0.6 & -0.1 & 0.9 \\
\hline Greece & 0.1 & 0.2 & -0.1 & 0.3 \\
\hline Hong Kong (SAR) & 1.1 & 0.5 & -0.5 & 1.1 \\
\hline India & 0.2 & 0.2 & -0.1 & 0.3 \\
\hline Indonesia & 0.8 & 0.6 & 0.1 & 1.5 \\
\hline Ireland & 10.0 & 1.9 & -0.4 & 11.5 \\
\hline Israel & 1.0 & 2.0 & -0.3 & 2.7 \\
\hline Italy & 0.5 & 0.5 & -0.2 & 0.8 \\
\hline Japan & 1.4 & 0.9 & 0.4 & 2.7 \\
\hline Korea & 2.0 & 2.0 & 3.6 & 7.6 \\
\hline Malaysia & 12.9 & 1.9 & 6.4 & 21.3 \\
\hline Netherlands & 0.9 & 0.3 & -0.2 & 1.0 \\
\hline Norway & 0.2 & 0.4 & -0.1 & 0.4 \\
\hline Philippines & 2.3 & 0.4 & 5.3 & 7.9 \\
\hline Portugal & 0.4 & 0.2 & -0.1 & 0.5 \\
\hline Singapore & 27.0 & 0.5 & 6.8 & 34.4 \\
\hline South Africa & 0.1 & 0.3 & -0.2 & 0.2 \\
\hline Spain & 0.3 & 0.5 & -0.1 & 0.6 \\
\hline Sweden & 0.1 & 3.5 & -0.4 & 3.1 \\
\hline Switzerland & 0.3 & 0.3 & -0.1 & 0.5 \\
\hline Taiwan Province of China & 7.5 & 0.6 & -0.7 & 7.4 \\
\hline Thailand & 5.8 & 0.5 & 0.0 & 6.2 \\
\hline United Kingdom & 1.1 & 0.8 & -0.2 & 1.8 \\
\hline United States & 1.0 & 0.8 & -0.1 & 1.7 \\
\hline
\end{tabular}

Source: Authors' calculations, based on Reed. See Section 3 for definitions of the respective categories of IT goods. 


\section{Appendix}

Table A2. IT Expenditure, 1996-2000 (Reed)

(Avg. share of GDP, 1996-2000)

\begin{tabular}{|c|c|c|c|}
\hline & EDP goods & $\begin{array}{l}\text { Communications } \\
\text { Equipment }\end{array}$ & Sum \\
\hline Australia & 1.2 & 0.3 & 1.5 \\
\hline Austria & 0.8 & 0.5 & 1.3 \\
\hline Belgium & 0.9 & 0.7 & 1.6 \\
\hline Brazil & 0.7 & 0.3 & 1.0 \\
\hline Canada & 1.1 & 0.3 & 1.4 \\
\hline Denmark & 1.1 & 0.4 & 1.5 \\
\hline Finland & 1.1 & 0.3 & 1.4 \\
\hline France & 0.7 & 0.7 & 1.4 \\
\hline Germany & 0.8 & 0.4 & 1.2 \\
\hline Greece & 0.4 & 0.7 & 1.0 \\
\hline Hong Kong (SAR) & 0.7 & 0.5 & 1.2 \\
\hline India & 0.3 & 0.1 & 0.4 \\
\hline Indonesia & 0.3 & 0.7 & 0.9 \\
\hline Ireland & 0.8 & 0.5 & 1.3 \\
\hline Israel & 0.9 & 0.4 & 1.3 \\
\hline Italy & 0.5 & 0.6 & 1.1 \\
\hline Japan & 0.8 & 0.4 & 1.2 \\
\hline Korea & 1.1 & 1.5 & 2.6 \\
\hline Malaysia & 0.9 & 0.6 & 1.5 \\
\hline Netherlands & 1.1 & 0.5 & 1.6 \\
\hline Norway & 1.0 & 0.5 & 1.5 \\
\hline Philippines & 0.5 & 0.7 & 1.2 \\
\hline Portugal & 0.6 & 0.4 & 1.1 \\
\hline Singapore & 1.3 & 1.1 & 2.4 \\
\hline South Africa & 1.2 & 0.7 & 1.9 \\
\hline Spain & 0.5 & 0.7 & 1.3 \\
\hline Sweden & 1.4 & 0.8 & 2.2 \\
\hline Switzerland & 1.2 & 0.6 & 1.7 \\
\hline Taiwan Province of China & 0.6 & 0.2 & 0.9 \\
\hline Thailand & 0.5 & 0.4 & 0.9 \\
\hline United King dom & 1.1 & 0.7 & 1.8 \\
\hline United States & 1.4 & 0.9 & 2.2 \\
\hline
\end{tabular}

Source: Authors' calculations, based on Reed. See Section 3 for definitions of the respective categories of IT goods. 


\section{Appendix}

Table A3. Relative Prices of IT Goods, 1996-2000

(Avg. annual rate of change, 1996-2000)

\begin{tabular}{|c|c|c|c|c|}
\hline & EDP goods & $\begin{array}{l}\text { Communications } \\
\text { Equipment }\end{array}$ & $\begin{array}{c}\text { Active } \\
\text { Components }\end{array}$ & Software \\
\hline Australia & -19.5 & 0.4 & -14.7 & 2.4 \\
\hline Austria & -16.7 & 3.9 & -11.7 & 6.0 \\
\hline Belgium & -16.8 & 3.8 & -11.8 & 5.9 \\
\hline Brazil & -17.5 & 3.0 & -12.5 & 5.1 \\
\hline Canada & -22.0 & -2.7 & -17.3 & -0.7 \\
\hline Denmark & -18.3 & 1.9 & -13.4 & 3.9 \\
\hline Finland & -17.2 & 3.3 & -12.2 & 5.4 \\
\hline France & -17.1 & 3.4 & -12.1 & 5.5 \\
\hline Germany & -16.4 & 4.4 & -11.4 & 6.5 \\
\hline Greece & -19.0 & 1.1 & -14.1 & 3.0 \\
\hline Hong Kong (SAR) & -22.0 & -2.6 & -17.3 & -0.7 \\
\hline India & -22.3 & -3.0 & -17.6 & -1.1 \\
\hline Indonesia & -17.1 & 3.4 & -12.2 & 5.5 \\
\hline Ireland & -20.5 & -0.9 & -15.8 & 1.1 \\
\hline Israel & -22.8 & -3.6 & -18.1 & -1.7 \\
\hline Italy & -20.3 & -0.6 & -15.6 & 1.4 \\
\hline Japan & -19.4 & 0.6 & -14.6 & 2.6 \\
\hline Korea & -17.3 & 3.2 & -12.3 & 5.3 \\
\hline Malaysia & -18.6 & 1.6 & -13.7 & 3.7 \\
\hline Netherlands & -17.3 & 3.2 & -12.4 & 5.2 \\
\hline Norway & -21.2 & -1.6 & -16.4 & 0.3 \\
\hline Philippines & -19.6 & 0.3 & -14.8 & 2.3 \\
\hline Portugal & -19.1 & 0.9 & -14.3 & 2.9 \\
\hline Singapore & -18.8 & 1.3 & -14.0 & 3.3 \\
\hline South Africa & -17.2 & 3.3 & -12.2 & 5.4 \\
\hline Spain & -18.5 & 1.7 & -13.6 & 3.7 \\
\hline Sweden & -19.0 & 1.0 & -14.2 & 3.0 \\
\hline Switzerland & -16.8 & 3.8 & -11.8 & 5.9 \\
\hline Taiwan Province of China & -20.2 & -0.4 & -15.4 & 1.6 \\
\hline Thailand & -16.7 & 3.9 & -11.7 & 6.0 \\
\hline United Kingdom & -23.5 & -4.6 & -18.9 & -2.6 \\
\hline United States & -23.4 & -4.5 & -18.8 & -2.5 \\
\hline
\end{tabular}

United States

$-2.5$

Source: Authors' calculations, based on US National Income and Product Accounts and US Producer Price Indices. 


\section{References}

Baily, M. N. (2001), 'Macroeconomic Implications of the New Economy', in Economic Policy for the Information Economy, A Symposium held in Jackson Hole, Wyoming and sponsored by the Federal Reserve Bank of Kansas City: Kansas City, Missouri, pp.201-268.

Brynjolfsson, E. (1994), 'Some Estimates of the Contribution of Information Technology to Consumer Welfare', unpublished, Sloan School of Management, Massachusetts Institute of Technology: Cambridge, Massachusetts.

Brynjolfsson, E. (1996), 'The Contribution of Information Technology to Consumer Welfare', Information Systems Research.

Brynjolfsson, E. and Hitt, L. M. (1995), 'Information Technology as a Factor of Production: the Role of Differences Among Firms', Economics of Innovation and New Technology, Vol. 3, No. 4, pp.183-200.

Brookes, M. and Wahhaj, Z. (2000), 'Is the Internet Better than Electricity?', Goldman Sachs Global Economics Papers No. 49, New York.

Cardarelli, R. (2001), 'Is Australia a 'New Economy'?', in Australia: Selected Issues and Statistical Appendix, IMF Country Report No. 01/55, International Monetary Fund: Washington.

Colecchia, A. (2001), 'The Impact of Information and Communications Technologies on Output Growth: Issues and Preliminary Findings', OECD Directorate for Science, Technology, and Industry Working Paper No. 11, Organization for Economic Cooperation and Development: Paris.

Crafts, N. (2000), 'The Solow Productivity Paradox in Historical Perspective', unpublished, London School of Economics.

Daveri, F. (2001), 'Information Technology and Growth in Europe', unpublished, University of Parma: Parma.

Deutsche Bank (2001), 'New Economy Everywhere — Except in Euro-Area Statistics', Economics Weekly, (April 6), pp.12-15.

Japan, Economic Planning Agency (2000), Economic Survey of Japan, Economic Planning Agency: Tokyo.

Estevao, M. and Levy, J. (2000), 'The New Economy in France: Development and Prospects', in France: Selected Issues, IMF Staff Country Report No. 00/148 International Monetary Fund: Washington.

Fogel, R. W. (1964), Railroads and American Economic Growth: Essays in Econometric History, Johns Hopkins University Press: Baltimore, Maryland. 
Gordon, R. J. (2000), 'Does the 'New Economy', Measure Up to the Great Inventions of the Past?', Journal of Economic Perspectives, Vol. 14, No.4, pp.49-74.

Gordon, R. J. (2002), 'Technology and Economic Performance in the American Economy', NBER Working Paper No. 8771 National Bureau of Economic Research: Cambridge, Massachusetts.

Harley, C. K. (1998), 'Cotton Textile Prices and the Industrial Revolution', Economic History Review, Vol. 51, pp.49-83.

Harley, C. K. (1999), 'Cotton Textile Prices Revisited: A Reply to Cuenca Esteban', Economic History Review, Vol. 52, pp.756-765.

Hitt, L. and Brynjolfsson, E. (1996), 'Productivity, Profit and Consumer Welfare', MIS Quarterly, Vol. 20, No. 2 (June).

International Monetary Fund (2001), 'The IT Revolution', Chapter 3 of World Economic Outlook: October 2001, International Monetary Fund: Washington.

Jorgenson, D. W. and Stiroh, K. V. (2000), 'Raising the Speed Limit: US Economic Growth in the Information Age', Brookings Papers on Economic Activity, pp.125-211.

Kodres, L. (2001), 'The New Economy in the United Kingdom', in United Kingdom: Selected Issues, IMF Country Report No. 01/124, International Monetary Fund: Washington.

Lee, F. C. and Pilat, D. (2001), 'Productivity Growth in ICT-Producing and ICT-Using Industries: A Source of Growth Differentials in the OECD?', OECD Directorate for Science, Technology, and Industry Working Paper No. 3, Organization for Economic Cooperation and Development: Paris.

Lee, I-H., and Khatri, Y. (2001), 'The Role of the New Economy in East Asia', unpublished, Asia and Pacific Department, International Monetary Fund: Washington.

Mairesse, J., Cette, G. and Kocoglu, Y. (2000), 'Les Technologies de l'Information et de la Communication en France: Diffusion et Contribution à la Croissance', Economie et Statistique, No. 339/340, pp.117-146.

Oliner, S. D. and Sichel, D. E. (2000), 'The Resurgence of Growth in the Late 1990s: Is Information Technology the Story?', Journal of Economic Perspectives, Vol. 14 (Fall), pp.3-22.

Oulton, N. (2001), 'ICY and Productivity Growth in the United Kingdom', Bank of England Working Paper No. 140, Bank of England: London.

Reed Electronics Research (2001), Yearbook of World Electronics Data, Reed Business Information. 
Roeger, W. (2001), 'The Contribution of Information and Communication Technologies to Growth in Europe and the United States: A Macroeconomic Analysis', Economic Papers, No. 147, European Commission: Brussels.

Schreyer, P. (2000), 'The Contribution of Information and Communication Technology to Output Growth: A Study of the G7 Countries', STI Working Paper 2000/2, Directorate for Science, Technology and Industry, Organization for Economic Cooperation and Development: Paris.

Schreyer, P. (2001), 'Computer Price Indices and International Growth and Productivity Comparisons', OECD Statistics Directorate, unpublished, Organization for Economic Cooperation and Development: Paris.

Stiroh, K. J. (2001), 'Information Technology and the US Productivity Revival: What Do the Industry Data Say?', unpublished, Federal Reserve Bank of New York: New York.

Van Ark, B. (2001), 'The Renewal of the Old Economy: Europe in an Internationally Comparative Perspective', unpublished, University of Groningen: Groningen.

Varian, H. (1984), Microeconomic Analysis $2^{\text {nd }}$ ed., Norton: New York.

Whelan, K. (2000), 'A Guide to the Use of Chain Aggregated NIPA Data', unpublished, Board of Governors of the Federal Reserve System.

World Information Technology Services Alliance (WITSA) (2001), Digital Planet. 


\section{CENTRE FOR ECONOMIC PERFORMANCE \\ Recent Discussion Papers}
A. B. Bernard
S. Redding
P. K. Schott
H. Simpson

546 M. GutiPrez-Doml nech

Factor Price Equalization in the UK?

545 S. Nickell

Employment Penalty After Motherhood in Spain

S. Redding

J. Swaffield

the Structure of Production

544 S. Machin
A. Manning

J. Swaffield

543 R. Belfield

D. Marsden

Where the Minimum Wage Bites Hard: the Introduction of the UK National Minimum Wage to a Low Wage Sector

Matchmaking: the Influence of Monitoring Environments on the Effectiveness of Performance Pay Systems

542 C. A. Pissarides

Consumption and Savings With Unemployment Risk: Implications for Optimal Employment Contracts

541 M. Amiti

C. A. Pissarides

Trade and Industrial Location with Heterogeneous Labor

540 G. Duranton

H. G. Overman

Testing for Localisation Using Micro-Geographic Data

539 D. Metcalf

Unions and Productivity, Financial Performance and Investment: International Evidence

$538 \quad$ F. Collard

R. Fonseca

R. MuZoz

Spanish Unemployment Persistence and the Ladder Effect

537 C. L. Mann

Home Bias, Transactions Costs, and Prospects for the

E. E. Meade

Euro: A More Detailed Analysis

536 M. Manacorda

Intergenerational Transfers and Household Structure.

E. Moretti

Why Do Most Italian Youths Live With Their Parents?

535 D. Quah

One Third of the World's Growth and Inequality 
534 D. Quah

533 R. Dickens

A. Manning

532 S. Machin

A. Manning

531 R. Lydon

A. Chevalier

530 A. Bryson

529 H. Gray

528 E. Mueller

A. Spitz

527 D. Acemoglu

J-S. Pischke

526 J. Schmitt

J. Wadsworth

525 S. Fernie

H. Gray

524 N. Crafts

A. J. Venables

523 E. E. Meade

D. Nathan Sheets

522 D. Quah

521 D. Quah
Matching Demand and Supply in a Weightless

Economy: Market Driven Creativity With and Without IPRs

Has the National Minimum Wage Reduced UK Wage Inequality?

The Structure of Wages in What Should be a

Competitive Labour Market

Estimates of the Effect of Wages on Job Satisfaction

The Union Membership Wage Premium: An Analysis Using Propensity Score Matching

Family Friendly Working: What a Performance! An Analysis of the Relationship Between the Availability of Family Friendly Policies and Establishment Performance

Managerial Ownership and Firm Performance in German Small and Medium-Sized Enterprises

Minimum Wages and On-the-Job Training

Give PC's a Chance: Personal Computer Ownership and the Digital Divide in the United States and Great Britain

It's a Family Affair: the Effect of Union Recognition and Human Resource Management on the Provision of Equal Opportunities in the UK

Globalization in History: a Geographical Perspective

Regional Influences on US Monetary Policy: Some Implications for Europe

Technology Dissemination and Economic Growth:

Some Lessons for the New Economy

Spatial Agglomeration Dynamics

To order a discussion paper, please contact the Publications Unit

Tel 02079557673 Fax 02079557595 Email info@cep.lse.ac.uk Web site http://cep.lse.ac.uk 